\title{
A BATTERY OF TESTS USED TO EVALUATE THE ABILITIES OF YOUNG BASKETBALL PLAYERS
}

\author{
Miljan Hadžović, Nikola Prvulović, Ana Lilić \& Bojan Jorgić \\ Faculty of Sport and Physical Education, University of Niš, Republic of Serbia
}

\begin{abstract}
Team success in basketball is related to knowing basketball techniques and tactics, along with certain abilities and characteristics of the players. Several different batteries of tests are used to examine the players' current psycho-physical state needed for the successful planning of the training processes. To determine the players' psycho-physical condition, relevant data are used, based on the results of tests of morphological, motor, cognitive, conative, functional and sociological characteristics and abilities. The aim of the current research was to present a battery of tests used to evaluate the abilities and characteristics of young basketball players, aged 12 to 19, identified following an analysis of published scientific research. The following electronic databases were used to collect recent research: PUbMed, J-GATE, DOAJ and Google Scholar. The analyzed works were published from 2007 to 2018. The results show that the most frequent means of measurement in research involving young players, were batteries of tests which included different types of vertical jumps used to examine explosive power. Other tests that were used are tests for the evaluation of morphological characteristics, aerobic endurance, anaerobic capacity, agility, coordination, and speed of recovery after intensive acyclic activity in basketball. Taking these findings into account, it is clear that modern basketball is characterized by important variations in the movement, morphological status, and physiological demands of the players, all of which are conditioned by the players' positions on the team. The results and analysis of those tests are important for creating a quality basketball player profile in all parts of the game.
\end{abstract}

Key words: progress in basketball, ability test, skill tests, preparing athletes, sports condition.

\section{INTRODUCTION}

Due to the necessary specific requirements of individual sports and sports disciplines, as well as the corresponding abilities and characteristics which the athletes must possess, the design of high quality training plans and programs in elite sport has become an imperative (Milanović, Šalaj, Gregov, 2011). A great number of studies involving basketball as one of the most popular and most followed ball sports in the world indicate the need to determine and apply the best possible methods for the evaluation and improvement of certain characteristics and abilities of the human body (Castanga et al., 2009; Raiola, 2011). It is widely known that numerous team sports played with a ball, including basketball and all its different variations, represent a very good way of increasing the level of physical activity and physical fitness (Mlinarić, 2015). Basketball competitions, and the physical activity required during competitions, represent an intermittent means of exercise with well-developed aerobic and anaerobic fitness (Castanga et al., 2009). The concept of success in any sport must be connected to knowledge of the characteristics of a certain sport, but also certain abilities and characteristics of the athletes themselves. Compiling relevant data on the morphological, physiological and motor characteristics of athletes in a certain sport is achieved by applying various tests, that is, batteries of tests.

The aim of this paper was to analyze the use of a battery of tests for the evaluation of the abilities and characteristics of basketball players aged 12 to 19 in papers published from 2007 to 2018.

\section{METHOD}

To compile research in which batteries of tests were used to evaluate the abilities and characteristics of basketball players with an average age of 12 to 19 , the following electronic databases were used: PubMed, J-GATE, DOAJ and Google Scholar. Only research papers from 2007 to 2008 were taken into consideration. When analyzing the databases, the following key words were used: progress in basketball, ability test, skill tests, preparing athletes, and sports condition. The titles, abstracts and entire texts of the selected papers were analyzed by several authors based on the set criteria. 


\section{Criteria for exclusion}

In order for a study to be accepted for the final analysis, it had to satisfy the following criteria:

- the research had to include male basketball players with an average age of 12 to 19;

- valid and reliable batteries of tests had to be used to evaluate the characteristics and abilities of young basketball players.

The studies which satisfied the set criteria were then analyzed and presented based on the following parameters: references (the first letter of the name of the author and year the research was published), the sample of participants (their health status, age, overall number, and subgroups of participants), the evaluated abilities and characteristics, and the tests used to evaluate the state of the young basketball players.

\section{RESULTS}

The search of the electronic database search turned out 782 studies on the selected topic. Based on a further analysis and application of the set criteria in accordance with the aim of this study, the final analysis, as can be seen from (Figure 1), included 10 studies which best reflect the complexity of the evaluation of the current psycho-physical status of young basketball players and basketball as a sport.

Figure 1. The analysis of the papers

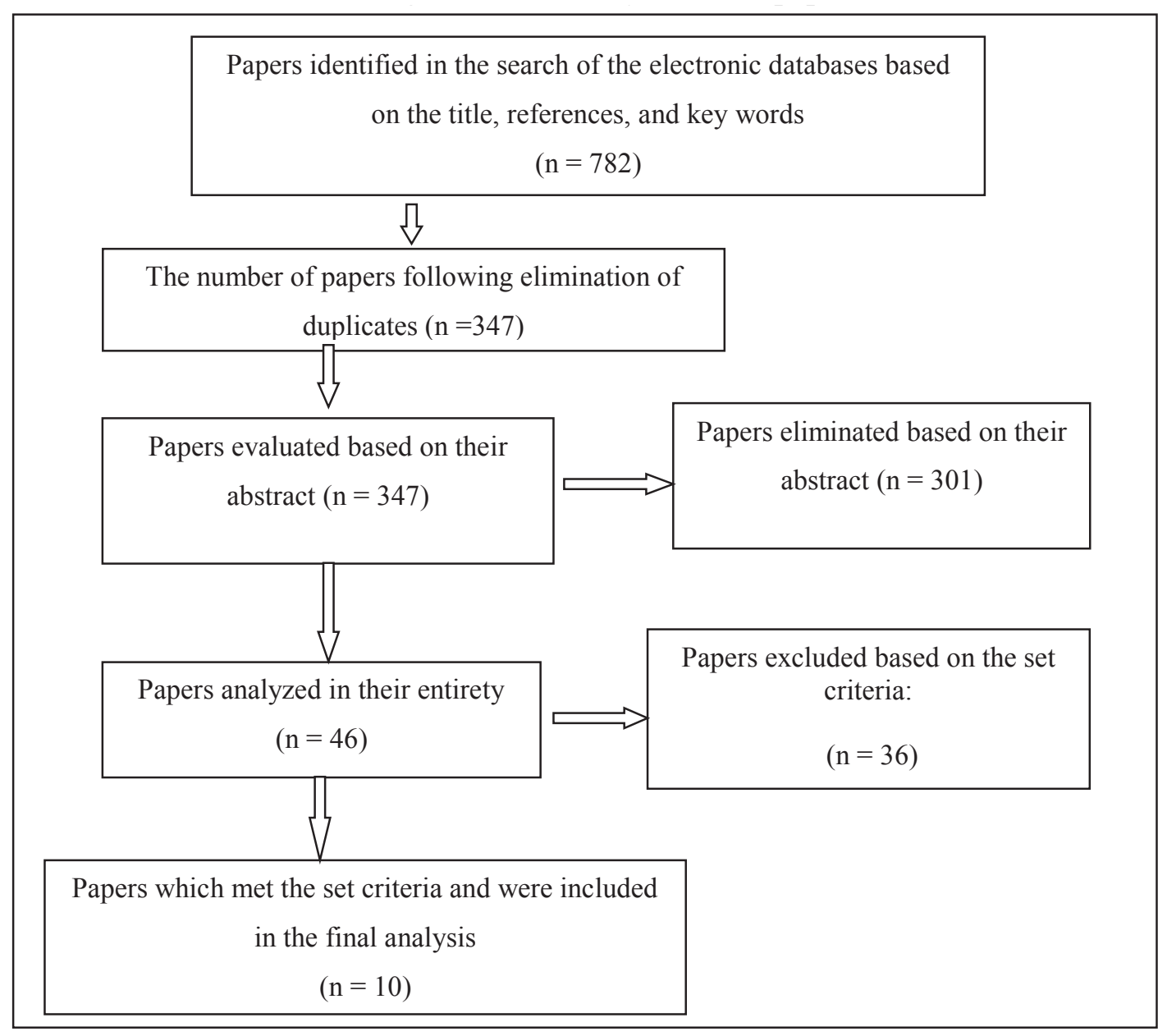


Table 1. A systematic overview and characteristics of the studies included in the analysis

\begin{tabular}{|c|c|c|c|c|c|c|c|c|c|c|}
\hline 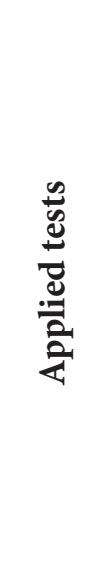 & 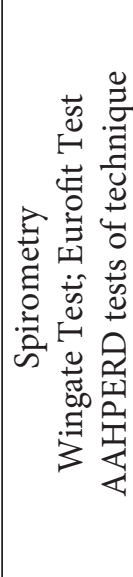 & 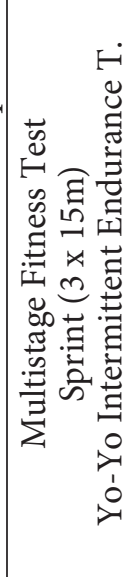 & 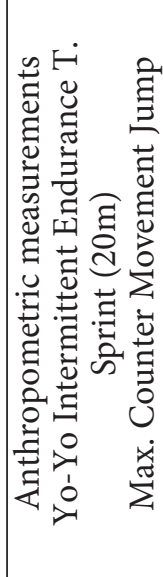 & 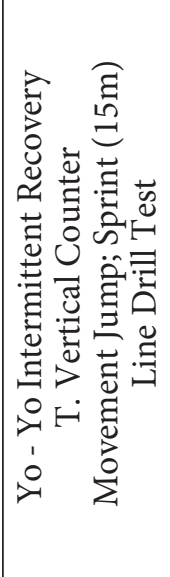 & 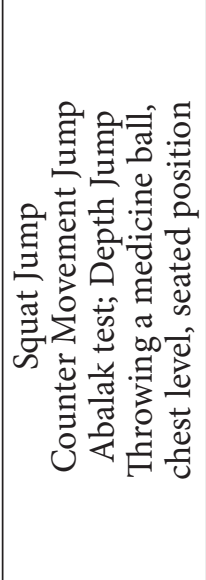 & 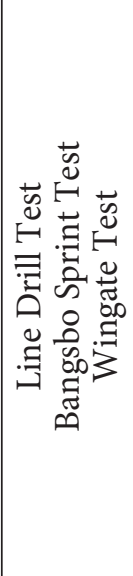 & 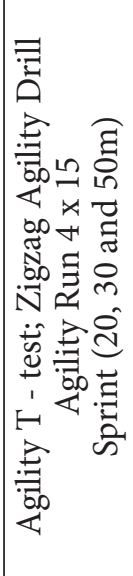 & 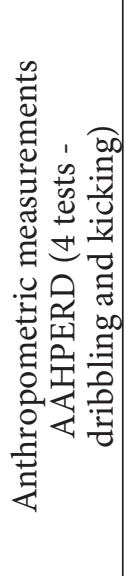 & 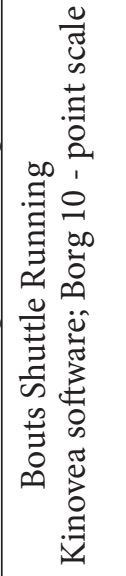 & 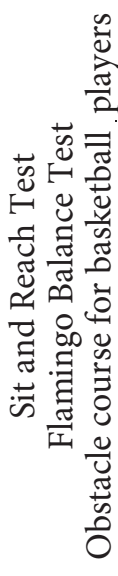 \\
\hline 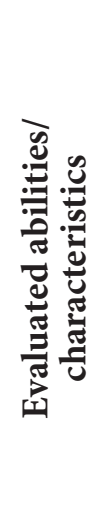 & 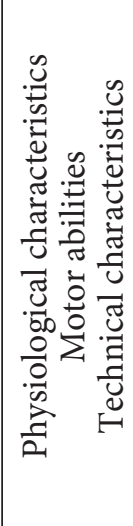 & 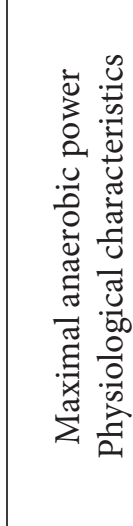 & 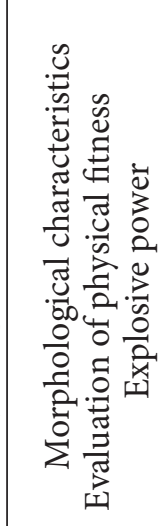 & 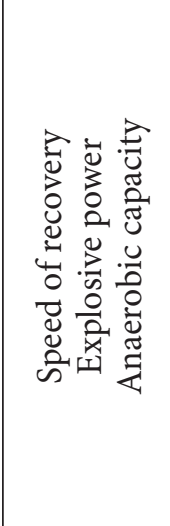 & 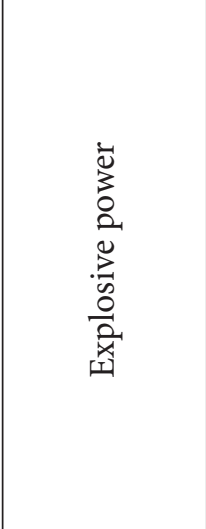 & 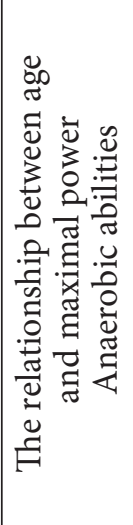 & 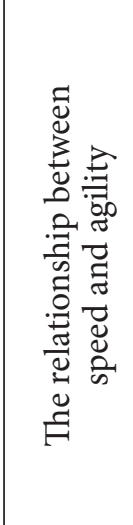 & 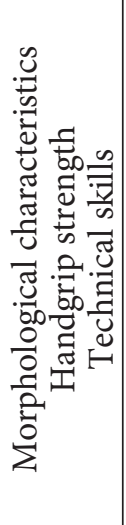 & 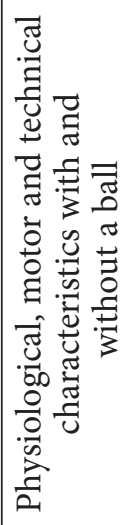 & 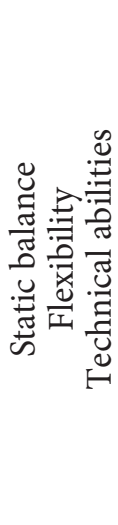 \\
\hline 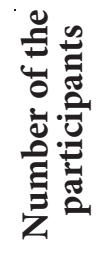 & $\begin{array}{l}\hat{} \\
\text { II } \\
=\end{array}$ & $\stackrel{\infty}{\stackrel{\infty}{\|}}$ & 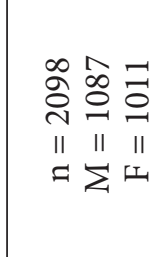 & $\begin{array}{l}\underset{N}{ } \\
\| \\
\beth\end{array}$ & $\begin{array}{l}\stackrel{10}{N} \\
\| \\
=\end{array}$ & $\begin{array}{l}\not{\sigma} \\
\text { II } \\
\text { I }\end{array}$ & 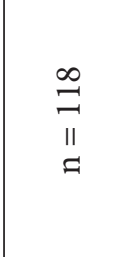 & $\begin{array}{l}8 \\
\text { II } \\
=\end{array}$ & 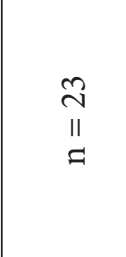 & $\begin{array}{l}\underset{N}{\text { II }} \\
\text { II }\end{array}$ \\
\hline & $\begin{array}{l}n \\
0 \\
+1 \\
\stackrel{+}{0} \\
\ddot{J}\end{array}$ & $\begin{array}{l}\sim \\
-1 \\
+1 \\
\infty \\
0 \\
-1\end{array}$ & 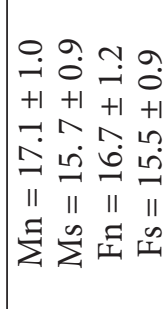 & $\begin{array}{l}0 \\
i \\
+1 \\
\infty \\
0 \\
0\end{array}$ & \begin{tabular}{l}
$\stackrel{2}{1}$ \\
$\dot{J}$ \\
\multirow{2}{*}{}
\end{tabular} & $\begin{array}{l}0 \\
\stackrel{1}{1} \\
\dot{J}\end{array}$ & 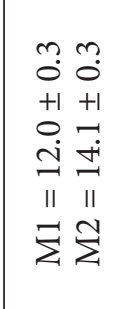 & $\begin{array}{l}\stackrel{H}{\prime} \\
\stackrel{1}{\sim}\end{array}$ & $\begin{array}{l}\infty \\
\stackrel{\infty}{1} \\
\stackrel{1}{ \pm} \\
\stackrel{+}{ \pm}\end{array}$ & $\begin{array}{l}\hat{0} \\
+1 \\
+1 \\
0 \\
0\end{array}$ \\
\hline 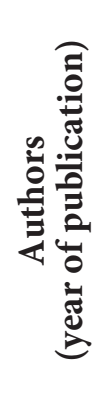 & 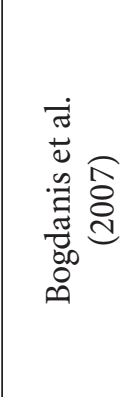 & 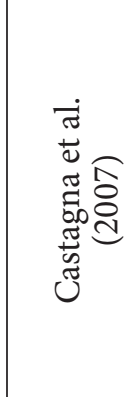 & 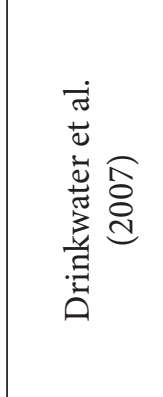 & 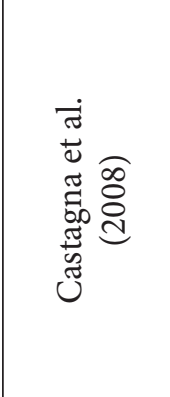 & 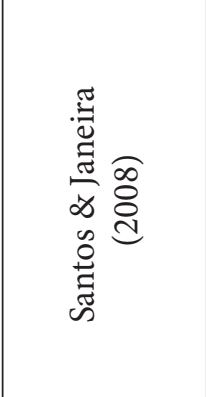 & 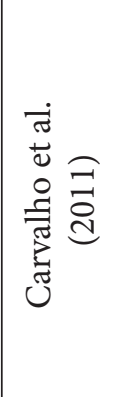 & 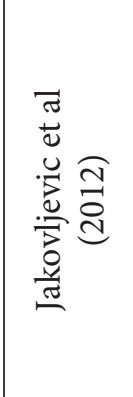 & 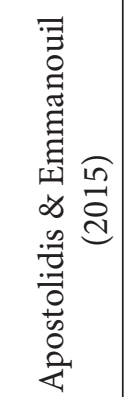 & 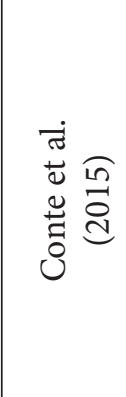 & 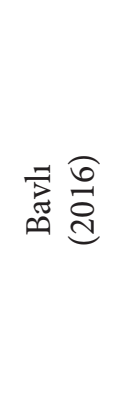 \\
\hline
\end{tabular}




\section{DISCUSSION AND CONCLUSION}

In order to evaluate the psycho-physical state of elite athletes, we used relevant data based on tests of various characteristics and abilities, including: morphological, motor, cognitive, conative, functional and sociological ones. The aims and tasks of the programmed exercise can be determined based on the diagnosed values, that is, by recognizing the positive and negative effect of the applied training sessions on athletes or teams (Milanović et al., 2011). In basketball, the interaction between morphological and functional characteristics, and motor abilities which actually determine the players' positions on the team, is very important (Drinkwater, Pyne, McKenna, 2008), as is the level of technical, tactical and psychological preparation of the players.

There are five players on the court during active play, and the positions of the players are mostly divided in two ways: players closer to the basket, those with greater height and mass (positions four and five) and players with body height and weight (positions one, two, and three) lower than that of the players in the first group, who are further from the basket and who occupy the 'outer' positions (Ostojic, Mazic, Dikic, 2006). That is why certain anthropometric data, which are evaluated using certain batteries of tests, are of great importance for the evaluation of the morphological model of the athlete (Ostojic, et al., 2006; Drinkwater et al., 2007; Drinkwater, et al., 2008; Köklü et al., 2011; Gonzalez et al., 2013; Popovic et al., 2014; Apostolidis, Emmanouil, 2015).

The great frequency of movement during active play, which is reflected in frequent jumps, sudden changes in direction, short and explosive sprints, and quick passes all classify basketball as a very demanding team sport (Matković, Matković, Knjaz, 2005). Certain motor skills which refer to solving motor tasks and lead to successful movement (Grbović, 2013) were frequently the subject matter of testing and evaluation in all the analyzed studies (Bogdanis et al., 2007; Castagna et al., 2007; Drinkwater et al., 2007; Castagna et al., 2008; Santos, Janeira, 2008; Carvalho et al., 2011; Jakovljevic et al., 2012; Apostolidis, Emmanouil, 2015; Conte et al., 2015; Bavl1, 2016). The study of (Blašković, Hofman, 1983) which analyzed the situations which take place during active play in basketball, along with their successful solutions, determined that a certain level of development of basic motor skills is needed. These skills include power, precision, speed, coordination, agility, and balance.

The batteries of tests for the evaluation of physiological characteristics are a frequent means of evaluating the state of health and fitness of young basketball players, and were used in six of the evaluated studies (Bogdanis et al., 2007; Castagna et al., 2007; Drinkwater et al., 2007; Castagna et al., 2008; Carvalho et al., 2011; Conte et al., 2015). According to Ostojic et al. (2006) there are divided opinions regarding whether basketball is primarily an aerobic or anaerobic sport, and the authors suggest that success in basketball depends more on anaerobic power than aerobic power and capacity. The physiological factors involved in basketball, such as oxygen uptake, heart rate, and amount of blood lactate, depend not only on the players' positions on the team, but also their level of physical fitness and the time they spend in active play (Matković et al., 2005). Based on the analysis of the selected studies, we could say that the physiological requirements of basketball are great and depend on the state of the cardiovascular system and metabolic capacity of the players, which supports the findings of McInnes et al. (1995).

Technique makes up a large part of the overall quality of the players, and is even more significant than physical fitness or individual tactics. In the analyzed studies, the evaluation of the technical abilities of young basketball players by applying various batteries of tests was carried out in four of them (Bogdanis et al., 2007; Apostolidis, Emmanouil, 2015; Conte et al., 2015; Bavl, 2016). Currently, there are numerous batteries of tests for the evaluation of the technique and tactics of players, and are primarily divided into attack and defensive skills, which depend on ball possession (McGee, 2007). In addition, certain authors consider that an integrative technical and tactical preparation in basketball creates the possibility for selecting and using real solutions in various situations, which represents one of the main goals during competitions (Bazanov, 2007).

Finally, the results of the analyzed studies have shown that batteries of tests which rely on various types of vertical jumps to study the explosive 
power of the legs represent the most frequently used means of measurements in research involving young basketball players. Based on the analysis of the given batteries of tests, the recommendation is that when working with young basketball players, in order to monitor their technical, tactical and fitness progress, the following tests of evaluation should be used: tests for the morphological characteristics of explosive power of the legs, speed, agility, coordination, specific basketball techniques, precision, anaerobic capacity, and aerobic endurance.

\section{REFERENCES}

Apostolidis, N. and Emmanouil, Z. (2015). The influence of the anthropometric characteristics and handgrip strength on the technical skills of young basketball players. Journal of Physical Education and Sport, 15(2), pp.330-337.

Bavli, Ö. (2016). Investigation into the Effects of Eight Weeks of Step Aerobic Dance Practice on Static Balance, Flexibility and Selected Basketball Skills in Young Basketball Players. Journal of education and training studies, 4(5), pp.233-238.

Bazanov, B. (2007). Integrative approach of the technical and tactical aspects in basketball coaching. Abstract. Tallinn University. Dissertations on Social Sciences, 30, pp.1736-3675.

Blašković, M. and Hofman, E. (1983). Povezanost između bazičnih motoričkih sposobnosti i uspješnosti u košarci [The connection between basic motor abilities and success in basketball]. Kineziologija, 15(2), pp.17-25.

Bogdanis, G.C., Ziagos, V., Anastasiadis, M. and Maridaki, M. (2007). Effects of two different shortterm training programs on the physical and technical abilities of adolescent basketball players. Journal of Science and Medicine in Sport, 10(2), pp.79-88.

Carvalho, H.M., Silva, M.J.C.E., Figueiredo, A.J., Gonçalves, C.E., Philippaerts, R.M., Castagna, C. and Malina, R.M. (2011). Predictors of maximal short-term power outputs in basketball players 14-16 years. European Journal of Applied Physiology, 111(5), pp.789-796.

Castagna, C., Chaouachi, A., Rampinini, E., Chamari, K. and Impellizzeri, F. (2009). Aerobic and explosive power performance of elite Italian regional-level basketball players. The Journal of Strength \& Conditioning Research, 23(7), pp.19821987.

Castagna, C., Impellizzeri, F.M., Rampinini, E., D'Ottavio, S. and Manzi, V. (2008). The Yo-Yo intermittent recovery test in basketball players. Journal of Science and Medicine in Sport, 11(2), pp.202-208.

Castagna, C., Manzi, V., D’ottavio, O., Annino, G., Padua, E. and Bishop, D. (2007). Relation between maximal aerobic power and the ability to repeat sprints in young basketball players. The Journal of Strength \& Conditioning Research, 21(4), pp.11721176.

Conte, D., Favero, T.G., Niederhausen, M., Capranica, L. and Tessitore, A. (2015). Physiological and technical demands of no dribble game drill in young basketball players. The Journal of Strength \& Conditioning Research, 29(12), pp.3375-3379.

Drinkwater, E.J., Hopkins, W.G., McKenna, M.J., Hunt, P.H. and Pyne, D.B. (2007). Modelling age and secular differences in fitness between basketball players. Journal of sports sciences, 25(8), pp.869-878. Drinkwater, E.J., Pyne, D.B. and McKenna, M.J. (2008). Design and interpretation of anthropometric and fitness testing of basketball players. Sports medicine, 38(7), pp.565-578.

Gonzalez, A.M., Hoffman, J.R., Rogowski, J.P., Burgos, W., Manalo, E., Weise, K., Fragala, M.S. and Stout, J.R. (2013). Performance changes in NBA basketball players vary in starters vs. nonstarters over a competitive season. The Journal of Strength \$ Conditioning Research, 27(3), pp.611-615.

Grbović, M.V. (2013). Merenje agilnosti u različito definisanim uslovima [Measuring agility in variously defined conditions]. (Doctoral dissertation, University of Belgrade, Faculty of Sport and Physical Education).

Jakovljevic, S.T., Karalejic, M.S., Pajic, Z.B., Macura, M.M. and Erculj, F.F. (2012). Speed and agility of 12and 14-year-old elite male basketball players. The Journal of Strength \& Conditioning Research, 26(9), pp.2453-2459.

Köklü, Y., Alemdaroğlu, U., Koçak, F., Erol, A. and Findıkoğlu, G. (2011). Comparison of chosen physical fitness characteristics of Turkish professional basketball players by division and playing position. Journal of human kinetics, 30, pp.99-106.

Matković, B., Matković, B. and Knjaz, D. (2005). Fiziologija košarkaške igre [Physiology of the game of basketball]. Hrvatski športskomedicinski vjesnik, 20(2), pp.113-124.

McGee, K. (2007). Coaching basketball technical and tactical skills. Human Kinetics, Champaign, IL. Milanović, D., Šalaj, S. and Gregov, C. (2011). Nove tehnologije u dijagnostici pripremljenosti sportaša [New technologies in the diagnosing the fitness 
levels of athletes]. Zbornik radova 20. Ljetne škole kineziologa Republike Hrvatske Dijagnostika u područjima edukacije, sporta, sportfiske rekreacije i kineziterapije, pp.38-45.

Mlinarić, M. (2015). Sportsko rekreacijski sadržaji na otvorenom kao dio svakodnevnog života [Open air sports recreational content as a part of everyday life]. (Doctoral dissertation, University of Zagreb, Faculty of Kinesiology).

Ostojic, S.M., Mazic, S. and Dikic, N. (2006). Profiling in basketball: Physical and physiological characteristics of elite players. Journal of strength and Conditioning Research, 20(4), p.740-744.

Popovic, S., Bjelica, D., Jaksic, D., \& Hadzic, R. (2014). Comparative Study of Anthropometric Measurement and Body Composition between
Elite Soccer and Volleyball Players. International Journal of Morphology, 32(1), pp. 267-274.

Raiola, G. (2011). A study on Italian primary school rules: neurophysiological and didactic aspects in physical education and sport. Journal of Physical Education \& Sport/Citius Altius Fortius, 11(2), pp. 153-158.

Santos, E.J. and Janeira, M.A. (2008). Effects of complex training on explosive strength in adolescent male basketball players. The Journal of Strength \& Conditioning Research, 22(3), pp. 903909.

Corresponding author: Miljan Hadžović, PhD student 18000 Niš, Serbia Email: miljanhadzovic@gmail.com 